\title{
Magnitude of Helicobacter pylori and associated risk factors among symptomatic patients attending at Jasmin internal medicine and pediatrics specialized private clinic in Addis Ababa city, Ethiopia
}

Gemechu Shiferaw ${ }^{1}$ and Dessie Abera ${ }^{2^{*}}$ (D)

\begin{abstract}
Background: More than $50 \%$ of the people are infected worldwide with $\mathrm{H}$. pylori which causes significant public health morbidity and mortality. The distribution is quite different from country to country. Hence, early information is very important to prevent upper gastrointestinal complications. The current study aimed to assess the magnitude of $\mathrm{H}$. pylori and associated risk factors among symptomatic patients attending at Jasmin internal medicine and pediatrics specialized private clinic from August 2017 until May 2018 in Addis Ababa city, Ethiopia.
\end{abstract}

Methods: A cross-sectional study was conducted among 487 patients with upper gastrointestinal tract complaints attending at Jasmin internal medicine and pediatrics specialized private clinic from August 2017 until May 2018. Convenient sampling technique was used to enroll participants. Information regarding to risk factors was assessed using structured questionnaire. Stool samples were collected for $\mathrm{H}$. pylori antigen test. Data was entered and analyzed using SPSS version20 statistical software and a $p$-value less than 0.05 was considered as statistically significant.

Results: The overall prevalence of $H$. pylori among participants using stool antigen was $36.8 \%(n=179 / 487)$. Regarding to family income status, those who have low monthly income were more likely to be infected with $H$. pylori infection ( $A O R=6.056, \mathrm{Cl} 95 \%=1.603-22.881, P=0.037$ ). In addition, families with low educational level were more likely to be infected with $H$. pylori infection than higher level education $(A O R=4.150, C 195 \%=1.059-16.270, P=0.041)$. Number of family members in the house-hold, type of toilet they used and source of drinking water were not significantly associated with H. pylori infection.

Conclusions: The prevalence of $\mathrm{H}$. pylori infection was $36.8 \%$ and it was related to low income and low education levels. This finding calls for improving the socioeconomic status of the community. Moreover, further studies are needed to investigate potential risk factors for $H$. pylori infection.

Keywords: Peptic ulcer, Dyspepsia, Bacteria, Stool antigen, Ethiopia

\footnotetext{
* Correspondence: dessabera@gmail.com

${ }^{2}$ Department of medical laboratory Sciences, Addis Ababa University, Addis

Ababa, Ethiopia

Full list of author information is available at the end of the article
}

(c) The Author(s). 2019 Open Access This article is distributed under the terms of the Creative Commons Attribution 4.0 International License (http://creativecommons.org/licenses/by/4.0/), which permits unrestricted use, distribution, and reproduction in any medium, provided you give appropriate credit to the original author(s) and the source, provide a link to the Creative Commons license, and indicate if changes were made. The Creative Commons Public Domain Dedication waiver (http://creativecommons.org/publicdomain/zero/1.0/) applies to the data made available in this article, unless otherwise stated. 


\section{Background}

Helicobacter pylori (H. pylori) infection is globally accepted as a major public health problem, with high burden in African countries [1]. In most cases, it is the cause of acute and chronic gastritis and highly associated to gastric cancer and peptic ulcer [2]. The bacterium causes peptic ulcer by eroding the epithelial tissue of the stomach and the upper part of the small intestine, which makes the stomach acid to get through to the sensitive lining layer. The inflammation in the lining of the stomach or duodenum is the combined effect of stomach acid and $H$. pylori, which leads to peptic ulceration [3]. Although the route of transmission of $H$. pylori infection is not clearly known, some evidences indicate that fecal contaminated water and food, faecal-oral contact and kissing are source of infection [4].

Helicobacter pylori infection is apparent in resource limited countries than in economically developed countries and the distribution varies between different communities and geographical locations [5]. About 50\% of the population is infected with $H$. pylori in affluent countries, whereas this percentage rises to $80 \%$ in developing countries [1], and the prevalence in Ethiopia is in the range of $48-95 \%$ [6].

The infection is often acquired during childhood and persists throughout life; remaining dormant for an extended period of time, and disease manifestations not appearing up to adulthood. The majorities of infected people are unaware of their infection status and remain to be infectious to others. Only some people develop illness, most of the time in adulthood [7]. Contributing factors for $H$. pylori infection are related to socio-demographic characteristics, personal and environmental hygiene, life style of the population, genetic predisposition and socioeconomic status [8].

The presence of $H$. pylori by itself is not a disease, but a condition, that causes the probability of developing various clinical disorders of the upper gastrointestinal tract. So, it should be integrated with the clinical history of an individual, which is very important to prevent the development of gastric cancer and peptic ulcer [9]. In addition, stool antigen testing is recommended for the diagnosis of $H$. pylori infection in patients with upper gastrointestinal symptoms [10]. In Ethiopia, many studies were used serology rapid tests but few data on stool antigen test which indicates active infection. Therefore, this study aimed to assess the prevalence of $H$. pylori and associated risk factors among symptomatic patients at Jasmin internal medicine and pediatric specialized private clinic, Addis Ababa, Ethiopia.

\section{Methods}

\section{Study design, period and area}

A cross-sectional study was conducted to determine the magnitude of $H$. pylori among symptomatic patients attending Jasmine internal medicine and pediatrics specialized clinic from August 2017 until May 2018. Jasmine internal medicine and pediatrics specialized clinic is a private clinic located in Addis Ababa city, Kolfe sub city. All the study participants were urban population. Patients with upper gastrointestinal tract complaints are frequently tested in the clinic, using stool antigen tests.

\section{Sample size determination and sampling technique}

Single population proportion formula, $\mathrm{n}=(\mathrm{Z} \alpha / 2)^{2} * \mathrm{P}$ $\left.(1-\mathrm{P}) / \mathrm{d}^{2}\right)$, was used to calculate the minimum sample size and the prevalence (p) taken was $48.7 \%$, from previous study in Assosa, Ethiopia (10), with a marginal error of 5 , and a 95\% confidence interval. Based on this calculation the sample size was 383. Nevertheless, we have collected 487 samples. All patients who have symptoms of $H$. pylori infection and who were volunteers to participate were included. Patients treated with any antibiotics like, omeprazole, amoxicillin, clarithromycin, bismuth subsalicylate, and lansoprazole, within the last 4 weeks, were excluded.

\section{Data collection procedure}

All age groups were included in the study, before data collection; written informed consent was obtained from study participants and children's parents, for those who were below 18 years old. The purpose of the study, the study procedures, possible risks/benefits, the rights and responsibilities of participants including their right to withdraw from the study at any time, was described.

Interviewer lead questionnaire was filled by parents/ guardians. Once all questions had been answered satisfactorily, parents/guardians who were interested in enrolling their children and themselves in the study were asked to sign an informed consent.

The parents were asked to complete a short questionnaire regarding to their daily habits, household information, and potential sources of infection. After this, the children and the parents were provided with a clean, dry, disinfectant free, wide mouthed plastic container to collect about $10 \mathrm{~g}$ of stool specimen into the container for $H$. pylori antigen test. Instruction was given how to prevent contamination of the stool with water and urine.

\section{Laboratory analysis \\ Stool antigen test}

Stool samples requested from each participating patient were collected in leak-proof containers. A small portion of the stool sample was transferred to a vial with diluents, vigorously agitated for $15 \mathrm{~s}$ and after that two to three drops were added into the round window of the test cassette. The results were interpreted after $15 \mathrm{~min}$ (according to the manufacturer's instruction) and we interpreted the results based on the appearance of 
colored lines across the central window of the cassette. Appearance of two lines, $\mathrm{C}$ (control) and $\mathrm{T}$ (test), indicates a positive test, and appearance of only one line, $\mathrm{C}$ (control) indicates a negative result.

\section{Data analysis and interpretation}

The completed data collection tool was checked for completeness and consistency and, was coded by the principal investigators. Data cleanup was performed to check for accuracy and consistencies. Any identified error was corrected immediately. Statistical analysis was performed using SPSS version 20. Descriptive statistics was used to describe the socio-demographic data, binary and multiple regression tests (odds ratio/adjusted odds ratio) were employed to assess the significant association between $H$. pylori and risk factors. A P-value of less than 0.05 was considered as statistically significant.

\section{Results}

Socio-demographic characteristics of study participants

A total of 487 patients participated in this study. The mean age of participants was $26.8 \pm 16.1 \mathrm{SD}$ (age range 3-75 years old). Majority of the study participants were females, 57.3\% (279/487). All the study participants were urban dwellers. About $85.6 \%$ of the participants' had a monthly between 3000 and 3500 Ethiopian birr. Regarding to educational status, university educational level accounted for the highest percentage, 90.8\% (442/487), as demonstrated below (Table 1).

\section{Distribution of $H$. pylori infection and its association with risk factors}

The prevalence of $H$. pylori in this study was $36.8 \%$ (179/ 487). The proportion of $H$. pylori was higher in females than males $(38.7 \%$ versus $34.1 \%)$ but the difference was not statistically significant $(p=0.301)$. Regarding family monthly income status, those who earn 1000-1500 and 2000-2500 Ethiopian birr were more likely to be affected with $H$. pylori infection $(\mathrm{COR}=7.150$, CI $95 \%=1.927-$ 26.524, $p=0.003$ and $\mathrm{COR}=9.350$, CI 95\% $=2.589-33.769$, $p=0.001)$ compared to those who earn3000-3500 Ethiopian birr $(p>0.05)$. Concerning educational status, primary level and secondary level education of the participants was significantly associated with $H$. pylori infection compared to higher level education $(\mathrm{COR}=6.555$, CI95\% $=1.777$ 24.1777, $p=0.005$ and COR $=3.277$, CI95 $\%=1.560-6.885$, $p=0.002)$ respectively.

The highest percentage, $46.7 \%$ (14/30), of H. pylori infections was noticed in the age group of 43-50 years old participants, followed by in the age group of 27-34 years old (40.5\%). Prevalence of $H$. pylori infection was slightly higher, 39.8\% (41/103) among participants who did not wash their hands than among participants who washed their hands after using toilet, 35.9\% (138/384). Number
Table 1 Socio-demographic characteristics of symptomatic patients at Jasmin internal medicine and pediatrics specialized clinic, Addis Ababa, Ethiopia, $2018(n=487)$

\begin{tabular}{|c|c|c|c|}
\hline Variables & & Frequency & Percent (\%) \\
\hline \multirow[t]{2}{*}{ Sex } & Female & 279 & 57.3 \\
\hline & Male & 208 & 42.7 \\
\hline \multirow[t]{7}{*}{ Age category in years } & $3-10$ & 93 & 19.1 \\
\hline & $11-18$ & 63 & 12.9 \\
\hline & $19-26$ & 112 & 23.0 \\
\hline & $27-34$ & 79 & 16.2 \\
\hline & $35-42$ & 65 & 13.3 \\
\hline & $43-50$ & 30 & 6.2 \\
\hline & $>50$ & 45 & 9.2 \\
\hline \multirow[t]{4}{*}{ Income } & $1000-1500$ & 5 & 1.0 \\
\hline & $2000-2500$ & 38 & 7.8 \\
\hline & $3000-3500$ & 417 & 85.6 \\
\hline & $>4000$ & 27 & 5.5 \\
\hline \multirow[t]{6}{*}{ Family number } & 1 & 26 & 5.3 \\
\hline & 2 & 66 & 13.6 \\
\hline & 3 & 252 & 51.7 \\
\hline & 4 & 118 & 24.2 \\
\hline & 5 & 22 & 4.5 \\
\hline & 6 & 2 & 4 \\
\hline \multirow[t]{3}{*}{ Educational status } & Primary & 13 & 2.6 \\
\hline & High school & 32 & 6.6 \\
\hline & University & 442 & 90.8 \\
\hline
\end{tabular}

COR Crude odds ratio, $\mathrm{Cl}$ Confidence interval

of family members, type of toilet they used and source of drinking water were not associated with $H$. pylori infection $(p>0.05)$ as showed (Table 2).

Multivariate analysis was performed for these factors that showed significant association at the crude odds ratio calculation. The association remains significant between $H$. pylori infection, income status and educational status (Table 3).

\section{Discussion}

The prevalence of $H$. pylori varies across the globe and this is partly due to socioeconomic difference [4]. H. pylori infection in symptomatic patients is highly associated with an increased risk of developing gastric cancer [11]. In this study, the overall prevalence of $H$. pylori was $36.8 \%(179 / 487)$ which was lower than studies done in Ethiopia, Gondar (85.6\%), Hawassa (62.3\%) and Asosa (48.7\%) [12-14] respectively, while it was higher than reported by Seid et al (30.4) [15]. The reason for this variation could be due to difference in sample size, laboratory testing methodology, good sanitation practice at individual and community level. Moreover, the above 
Table 2 Distribution of $H$. pylori infection and its association with risk factors among symptomatic patients at Jasmin internal medicine and pediatrics specialized clinic, Addis Ababa, Ethiopia, 2018( $\mathrm{n}=487)$

\begin{tabular}{|c|c|c|c|c|c|c|c|}
\hline \multirow[t]{2}{*}{ Variables } & & \multirow[t]{2}{*}{ Total } & \multicolumn{2}{|c|}{ Stool antigen } & \multirow[b]{2}{*}{ COR } & \multirow[b]{2}{*}{ Cl 95\% } & \multirow[b]{2}{*}{$P$-value } \\
\hline & & & Positive & Negative & & & \\
\hline \multirow[t]{2}{*}{ Sex } & Female & 279 & 108(38.7) & $171(61.3)$ & 1.219 & $0.838-1.772$ & 0.301 \\
\hline & Male & 208 & $71(34.1)$ & 137(65.9) & 1 & & \\
\hline \multirow[t]{7}{*}{ Age category } & $3-10$ & 93 & $30(32.3)$ & $63(67.7)$ & 0.863 & $0.408-1.826$ & 0.700 \\
\hline & $11-18$ & 63 & $24(38.1)$ & $39(61.9)$ & 1.115 & $0.504-2.469$ & 0.788 \\
\hline & $19-26$ & 112 & $41(36.6)$ & $71(63.4)$ & 1.047 & $0.509-2.153$ & 0.901 \\
\hline & $27-34$ & 79 & $32(40.5)$ & $47(59.5)$ & 1.234 & $0.578-2.633$ & 0.587 \\
\hline & $35-42$ & 65 & $22(33.8)$ & $43(66.2)$ & 0.927 & $0.418-2.059$ & 0.853 \\
\hline & $43-50$ & 30 & $14(46.7)$ & $16(53.3)$ & 1.586 & $0.618-4.067$ & 0.337 \\
\hline & $>50$ & 45 & 16(35.6) & $29(64.4)$ & 1 & & \\
\hline \multirow[t]{4}{*}{ Income } & 1000-1500 & 21 & 13(61.9) & $8(38.1)$ & 7.150 & $1.927-26.524$ & 0.003 \\
\hline & $2000-2500$ & 25 & $17(68.0)$ & $8(32.0)$ & 9.350 & 2.589-33.769 & 0.001 \\
\hline & $3000-3500$ & 414 & 144(34.8) & $270(65.2)$ & 2.347 & $0.870-6.327$ & 0.092 \\
\hline & $>4000$ & 27 & $5(18.5)$ & $22(81.5)$ & 1 & & \\
\hline \multirow[t]{2}{*}{ Family number } & $1-3$ & 345 & 127(36.8) & 218(63.2) & 1 & & \\
\hline & $4-6$ & 142 & $52(36.6)$ & $90(63.4)$ & 0.992 & $0.661-1.488$ & 0.968 \\
\hline \multirow[t]{3}{*}{ Education status } & Primary & 13 & 10(76.9) & $3(23.1)$ & 6.555 & $1.777-24.177$ & 0.005 \\
\hline & High school & 32 & $20(62.5)$ & $12(37.5)$ & 3.277 & $1.560-6.885$ & 0.002 \\
\hline & University & 442 & 149(33.7) & $293(66.3)$ & 1 & & \\
\hline \multirow[t]{2}{*}{ Type of toilet } & Flush & 413 & 154(37.3) & $259(62.7)$ & 1 & & \\
\hline & Pit latrine & 74 & 25(33.8) & $49(66.2)$ & 0.858 & $0.509-1.445$ & 0.565 \\
\hline \multirow[t]{3}{*}{ Water source } & Tap water & 429 & 163(38.0) & $266(62.0)$ & 1.532 & $0.660-3.558$ & 0.321 \\
\hline & Boiled water & 30 & $8(26.7)$ & $22(73.3)$ & 0.909 & $0.287-2.877$ & 0.871 \\
\hline & Bottle water & 28 & $8(28.6)$ & 20(71.4) & 1 & & \\
\hline \multirow[t]{2}{*}{ Hand wash after toilet } & Yes & 384 & 138(35.9) & $246(64.1)$ & 0.488 & $0.543-1.325$ & 0.470 \\
\hline & No & 103 & 41(39.8) & $62(60.2)$ & 1 & & \\
\hline
\end{tabular}

studies were used antibody test which may lead to over estimation of prevalence.

Our finding also less than studies reported in Brazil (78.8\%) [16], Beninese (74\%) [17], and China (48\%) [18], whereas it was higher than studies conducted in
Switzerland (18.9\%), Denmark (22.1\%), New Zealand (24.0\%), Australia (24.6\%), and Sweden (26.2\%) [1]. The difference might be due to variation in study design and large sample size in their study and the fact that $H$. pylori infection has strong association with socioeconomic status. In

Table 3 Adjusted odds ratio for monthly income and education with $H$. pylori infection among symptomatic patients attending at Jasmin internal medicine and pediatrics specialized clinic, Addis Ababa, Ethiopia, 2018 ( $n=487)$

\begin{tabular}{|c|c|c|c|c|c|c|c|}
\hline \multirow[t]{2}{*}{ Variables } & & \multicolumn{3}{|c|}{ Stool antigen } & \multirow[b]{2}{*}{ AOR } & \multirow[b]{2}{*}{$\mathrm{Cl} 95 \%$} & \multirow[b]{2}{*}{$P$-value } \\
\hline & & Total & Positive n (\%) & Negative n (\%) & & & \\
\hline \multirow[t]{4}{*}{ Income level } & $1000-1500$ EB & 21 & 13(61.9) & $8(38.1)$ & 4.316 & $1.093-17.038$ & 0.037 \\
\hline & $2000-2500$ EB & 25 & $17(68.0)$ & $8(32.0)$ & 6.056 & $1.603-22.881$ & 0.008 \\
\hline & $3000-3500 \mathrm{~EB}$ & 414 & 144(34.8) & $270(65.2)$ & 2.222 & $0.823-5.997$ & 0.115 \\
\hline & $>4000 \mathrm{~EB}$ & 27 & $5(18.5)$ & $22(81.5)$ & 1 & & \\
\hline \multirow[t]{3}{*}{ Education level } & Primary & 13 & 10(76.9) & $3(23.1)$ & 4.150 & $1.059-16.270$ & 0.041 \\
\hline & High school & 32 & $20(62.5)$ & $12(37.5)$ & 2.280 & $1.025-5.067$ & 0.043 \\
\hline & University & 442 & 149(33.7) & 293(66.3) & 1 & & \\
\hline
\end{tabular}


other words, in countries with high socioeconomic status, there is good hygiene practice, environmental sanitation and adequate provision of safe water which can reduce the prevalence rate.

There is no consensus on the state of being male or female as a risk factor for $H$. pylori infection but a study suggested that physiological difference between female and male may affect the mechanism of immune response to the pathogenesis of the bacterium [19]. In the current study, the proportion of $H$. pylori was higher in females, 38.7\% (108/279) than males, 34.1\% (71/208), but the difference was not statistically significant $(P>$ 0.05). The number of female participants was greater than male participants; this might be the reason why the prevalence of $H$. pylori in female participants was higher than males. However, further large scale studies on sex specific $H$. pylori infection is needed to explain this variation. This finding was consistent with previous studies done in Ethiopia [12, 13, 15, 20] and Kenya [21]. In contrast, other studies showed that $H$. pylori infection was significantly higher in males than females $[19,22]$.

Mostly people get their primary $H$. pylori infection during childhood and stay infected during their life time, however it is not clear when the acquisition is takes place $[23,24]$. Our study indicated high proportion of $H$. pylori infection in the age groups of $43-50$ years old $46.7 \%(14 / 30)$, however, this difference was not significant $(p>0.05)$. This was comparable to, previous studies conducted in Ethiopia, showed no significant association between age and $H$. pylori infection [13, 25]. Contrary to this, significant association between age and $H$. pylori infection was reported in Ethiopia, Butajira [26]. Source of drinking water has been noticed as one of the contributing factors for the high prevalence of $H$. pylori infection, this is apparent in developing countries where there is lack of access to clean water and poor sewerage system [27]. The relationship between source of drinking water and $H$. pylori infection was not statistically significant $(p>0.05)$. This result was similar to previous report in Ethiopia [13] and China [28].

Education and income status is strongly associated with $H$. pylori infection and this is one of the reasons to the wide variation in the prevalence of this infection between countries [29]. Countries with low socioeconomic status, like Ethiopia, there is poor personal hygienic practice, poor waste disposal system, crowded living conditions and lack of clean and safe water which are known to make individuals susceptible for infection [30] . In our finding, $H$. pylori infection was significantly higher in low-income households $(p=0.008)$, which was similar to the above concept and this was in agreement with other reports that have identified low income as a risk-factor predisposing to infection [31]. However, this was incongruent to a study done in Benine [17]. The current study indicated that low educational level was showed statistical significant association with prevalence of $H$. pylori infection $(p=0.041)$. This association could be due to the fact that inadequate education or low education level has a significant impact on personal hygiene and environmental hygiene and play a great role in the rise of the prevalence of $H$. pylori infection [21, 25, 27]. In contrast, previous study reported from Ethiopia, Assosa revealed that education level was not associated with $H$. pylori infection [13].

\section{Limitation}

The limitation of this study was unable to include asymptomatic individuals, which confines the true prevalence of H. pylori infection.

\section{Conclusion}

In conclusion, our study indicated that low income level and low educational status were significantly associated with $H$. pylori infection, but it was not related with source of drinking water, age and gender. Improving the socioeconomic status of the community will reduce the transmission and the burden of $H$. pylori infection. Further studies are needed to investigate potential risk factors for $H$. pylori infection.

\section{Abbreviations}

AOR: Adjusted odds ratio; COR: Crude odds ratio

\section{Acknowledgments}

We would like to express our gratitude to all the study participants for their willingness and patience during the study. We are thankful to Marrigje Jacoba Kreuger (MD) for her review and editing of the manuscript. Finally, our special thanks go to the Jasmin internal medicine and pediatrics specialized clinic administration for their unreserved support during the data collection.

\section{Funding}

No funding was obtained for this study.

Availability of data and materials

The datasets used and/or analyzed during the current study are available from the corresponding author on reasonable request.

\section{Authors' contributions}

DA conceived the study, designed the experiments, supervised the work and carried out the analysis. GSH participated in the recruitment of subjects and performed the physical examination of participants. All the authors read and approved the final manuscript.

\section{Ethics approval and consent to participate}

Ethical approval was given by research and ethics review committee of school of medicine, College of Health Sciences, Addis Ababa University. In addition, a formal letter of cooperation was requested from Jasmin internal medicine and pediatrics specialized clinic. Written informed consent was obtained from study participants and parents in the case of children under 18 years old. The respondents were informed about the right to refuse to take part in the study as well as to withdraw at any time during the study period. Results were kept confidential and $H$. pylori antigen positive participants were linked to the immediate responsible physician for better management or treatment. 


\section{Consent for publication}

Not applicable.

\section{Competing interests}

The authors declare that they have no competing interests.

\section{Publisher's Note}

Springer Nature remains neutral with regard to jurisdictional claims in published maps and institutional affiliations.

\section{Author details}

'School of medicine, Addis Ababa University, Addis Ababa, Ethiopia. ${ }^{2}$ Department of medical laboratory Sciences, Addis Ababa University, Addis Ababa, Ethiopia.

Received: 27 August 2018 Accepted: 29 January 2019

Published online: 06 February 2019

\section{References}

1. Hooi JK, Lai WY, Ng WK, Suen MM, Underwood FE, Tanyingoh D, et al. Global prevalence of Helicobacter pylori infection: systematic review and meta-analysis. J Gastroentrol. 2017:153(2):420-9.

2. Perez-Perez Gl, Rothenbacher D, Brenner H. Epidemiology of Helicobacter pylori infection. Helicobacter. 2004;9:1-6.

3. Yamada T, Searle JG, Ahnen D, Aipers DH, Greenberg HB, Gray M, et al. Helicobacter pylori in peptic ulcer disease. JAMA. 1994:272(1):65-9.

4. Goh KL, Chan WK, Shiota S, Yamaoka Y. Epidemiology of Helicobacter pylor infection and public health implications. Helicobacter. 2011;16:1-9.

5. Lu C, Yu Y, Li L, Y U C, Xu P. Systematic review of the relationship of Helicobacter pylori infection with geographical latitude, average annual temperature and average daily sunshine. BMC Gastroentrol. 2018;18(1):50.

6. Hunt R, Xiao S, Megraud F, Leon-Barua R, Bazzoli F, Van der Merwe S, et al. Helicobacter pylori in developing countries. World gastroenterology organisation global guideline. J Gastrointestin Liver Dis. 2011;20(3):299-304

7. Korkmaz H, Kesli R, Karabagli P, Terzi Y. Comparison of the diagnostic accuracy of five different stool antigen tests for the diagnosis of Helicobacter pylori infection. Helicobacter. 2013;18(5):384-91.

8. Dube C, Tanih N, Clarke A, Mkwetshana N, Green E, Ndip R. Helicobacter pylori infection and transmission in Africa: household hygiene and water sources are plausible factors exacerbating spread. Afr J Biotechnol. 2009; 8(22):6028-35.

9. Kusters JG, van Vliet AH, Kuipers EJ. Pathogenesis of Helicobacter pylor infection. Clin Microbiol Rev. 2006;19(3):449-90.

10. Lopes Al, Vale FF, Oleastro M. Helicobacter pylori infection-recent developments in diagnosis. World J Gastroenterol. 2014;20(28):9299.

11. Wroblewski LE, Peek RM, Wilson KT. Helicobacter pylori and gastric cancer: factors that modulate disease risk. Clin Microbiol Rev. 2010;23(4):713-39.

12. Mathewos B, Moges B, Dagnew M. Seroprevalence and trend of Helicobacter pylori infection in Gondar University hospital among dyspeptic patients, Gondar, North West Ethiopia. BMC Res Notes. 2013;6(1):346.

13. Dilnessa T, Amentie M. Prevalence of Helicobacter pylori and risk factors among dyspepsia and non-dyspepsia adults at Assosa general hospital, West Ethiopia: a comparative study. Ethiop J Health Dev. 2017;31(1):4-12.

14. Tadesse E, Daka D, Yemane D, Shimelis T. Seroprevalence of Helicobacter pylori infection and its related risk factors in symptomatic patients in southern Ethiopia. BMC Res note. 2014;7(1):834.

15. Seid A, Demsiss W. Feco-prevalence and risk factors of Helicobacter pylori infection among symptomatic patients at Dessie referral hospital, Ethiopia. BMC Infect Dis. 2018:18(1):260.

16. Almeida Cunha R, Alves F, Rocha A, Rocha G, Camargo L, Nogueira P, et al. Prevalence and risk factors associated with Helicobacter pylori infection in native populations from Brazilian Western Amazon. Trans R S Trop Med Hyg. 2003;97(4):382-6.

17. Aguemon BSM, Massougbodji A, Ouendo EM. Prevalence and risk-factors for Helicobacter pylori infection in urban and rural Beninese populations. Clin Microbiol Infect. 2005:11(8):611-7.

18. Cheng H, Hu F, Zhang L, Yang G, Ma J, Hu J, et al. Prevalence of Helicobacter pylori infection and identification of risk factors in rural and urban Beijing, China. Helicobacter. 2009;14(2):128-33.

19. Ibrahim AMS, Ferro A, Lunet N, Peleteiro B. Sex-differences in the prevalence of Helicobacter pylori infection in pediatric and adult populations: systematic review and meta-analysis of 244 studies. Dig Liver Dis. 2017:49(7):742-9.

20. Tadege T, Mengistu Y, Desta K, Asrat D. Serioprevalence of Helicobacter pylori infection in and its relationship with $\mathrm{ABO}$ blood groups. Ethiop J Health Dev. 2005;19(1):55-9.

21. Shmuely H, Obure S, Passaro DJ, Abuksis G, Yahav J, Fraser G, et al. Dyspepsia symptoms and Helicobacter pylori infection, Nakuru, Kenya. Emerg Infect Dis. 2003;9(9):1103.

22. Broutet N, Sarasqueta A-M, Sakarovitch C, Cantet F, Lethuaire D, Mégraud F. Helicobacter pylori infection in patients consulting gastroenterologists in France: prevalence is linked to gender and region of residence. Eur J Gastroen Hepat. 2001;13(6):677-84.

23. Atherton JC, Blaser MJ. Coadaptation of Helicobacter pylori and humans: ancient history, modern implications. J Clin Invest. 2009;119(9):2475-87.

24. Pérez-Pérez GI, Sack RB, Reid R, Santosham M, Croll J, Blaser MJ. Transient and persistent Helicobacter pylori colonization in native American children. J Clin Microbiol. 2003:41(6):2401-7.

25. Abebaw W, Kibret M, Abera B. Prevalence and risk factors of $H$. pylori from dyspeptic patients in Northwest Ethiopia: a hospital based cross-sectional study. Asian Pac J Cancer Prev. 2014;15(11):4459-63.

26. Kibru D, Gelaw B, Alemu A, Addis Z. Helicobacter pylori infection and its association with anemia among adult dyspeptic patients attending Butajira hospital, Ethiopia. BMC Infect Dis. 2014;14(1):656

27. Nurgalieva ZZ, Malaty HM, Graham DY, Almuchambetova R, Machmudova A, Kapsultanova D, et al. Helicobacter pylori infection in Kazakhstan: effect of water source and household hygiene. Am J Trop Med Hyg. 2002;67(2):201-6.

28. Shi $R$, Xu S, Zhang $H$, Ding $Y$, Sun $G$, Huang $X$, et al. Prevalence and risk factors for Helicobacter pylori infection in Chinese populations. Helicobacter. 2008;13(2):157-65.

29. Malaty HM. Epidemiology of Helicobacter pylori infection. Best Pract Res Clin Gastroenterol. 2007:21(2):205-14

30. Chen H-L, Chen M-J, Shih S-C, Wang H-Y, Lin I-T, Bair M-J. Socioeconomic status, personal habits, and prevalence of Helicobacter pylori infection in the inhabitants of Lanyu. J Formos Med Assoc. 2014;113(5):278-83.

31. Deltenre M. How come I've got it? (a review of Helicobacter pylori transmission). Eur J Gastroenterol Hepatol. 2000;12(5):479-82.
Ready to submit your research? Choose BMC and benefit from:

- fast, convenient online submission

- thorough peer review by experienced researchers in your field

- rapid publication on acceptance

- support for research data, including large and complex data types

- gold Open Access which fosters wider collaboration and increased citations

- maximum visibility for your research: over $100 \mathrm{M}$ website views per year

At $\mathrm{BMC}$, research is always in progress.

Learn more biomedcentral.com/submissions 